Max-Planck-Institut für demografische Forschung

Max Planck Institute for Demographic Research

Doberaner Strasse 114 - D-18057 Rostock · GERMANY

Tel +49 (0) 3812081 - 0; Fax +49 (0) 3812081 - 202;

http://www.demogr.mpg.de

MPIDR WORKING PAPER WP 2000-009

OCTOBER 2000 (Revised 8 June 2001)

The Public Perception and Discussion

of Falling Birth Rates:

The Recent Debate Over Low Fertility

in the Popular Press

Laura Stark (1stark@princeton.edu)

Hans-Peter Kohler (kohler@demogr.mpg.de)

(C) Copyright is held by the authors.

Working papers of the Max Planck Institute for Demographic Research receive only limited review. Views or opinions expressed in working papers are attributable to the authors and do not necessarily reflect those of the Institute. 


\title{
The Public Perception and Discussion of Falling Birth Rates: The Recent Debate Over Low Fertility in the Popular Press
}

\author{
Laura Stark \\ Office of Population Research \\ 219 Wallace Hall, Princeton University \\ Princeton, New Jersey 08540 USA \\ Lstark@princeton.edu \\ 609-258-4941 \\ Hans-Peter Kohler \\ Max Planck Institute for Demographic Research \\ Doberaner Strasse 114 \\ 18057 Rostock Germany \\ Kohler@demogr.mpg.de \\ +49 (0)381-2081-123
}

June 4, 2001

\begin{abstract}
Aspects of below-replacement fertility have long been debated among academics. Analyzing 437 popular newspaper and magazine articles from eleven developed countries during 1998-99, this study describes the corresponding public debate about low fertility. Despite the diversity in the national debates of the eleven countries due to different socioeconomic, political and demographic backgrounds, our study finds important commonalties among the public debates about low fertility: First, countries emphasize consequences and potential interventions rather than causes in their public debate over low fertility. Second, our study reveals that the popular press discusses low fertility as a serious concern with mostly negative implications, despite the fact that many of the causes of low fertility are associated with social and economic progress. Third, the variety of issues and perspectives revealed in the public debate, while cohesive in general ways, invites a role for demographers in informing an accurate public discussion of low fertility, which will help form the most appropriate policy outcomes.
\end{abstract}




\section{Introduction}

Low fertility has become quite commonplace worldwide, and Europe has experienced below replacement fertility for several decades. Yet, total fertility rates that approach levels of 1.0, as they do in Italy, Spain, Bulgaria, and other Eastern European countries, or total fertility rates that are even below 1.0, as in eastern Germany and parts of Italy, are a relatively new phenomenon. This decline in birth rates did not pass demographers unnoticed; they initiated substantial new interest about the possible endpoints of the fertility decline and the relation of current fertility trends to socioeconomic conditions. In addition to demographers' interest in low fertility, the rapid and sometimes extreme changes in fertility patterns in the last decade moved the issue of low fertility beyond professional conferences and communications into the public forum. Emerging is not only an active public debate about the causes and consequences of low fertility levels, but also a shift in the public conscience from alarm over too many people to fears of too few.

This evolution begs the question of how the recent public debate over low fertility is framed in various countries. This paper seeks to describe which causes and consequences of low fertility feature most prominently in public debates; which causes and consequences are emphasized in the corresponding academic debate; which interventions towards changing or accommodating the recent trends are favored in the popular press; and what public opinion towards low fertility implies for policy interventions. Understanding how low fertility is debated in the popular press is not only interesting in its own right, but it is also essential knowledge for demographers in order to contribute actively to both the popular debate on low fertility and also the 
debate on public policy reactions. When demographers can draw on professional knowledge about the measurements, determinants and implications of belowreplacement fertility and also cultivate an awareness of the public perception of low fertility, they will succeed in contributing to the public debate on low fertility and the corresponding debate in the public policy arena. Participating in the sometimes erroneously framed and incompletely informed public debate will aid in appropriately adjusting or reshaping policies in order to change or accommodate the recent developments.

In this paper we therefore describe patterns in how countries attribute the causes and consequences of low fertility, and the expressed concerns and "fears" in the recent public debate over contemporary low fertility. These investigations are based on the popular press - that is, leading national or regional newspapers or magazines, of eleven developed countries. Admittedly, the popular press blurs some nuances of public conscience and is only a partial representation of the public debate about low fertility. However, in comparing public discourse across the breadth of four continents, the popular press can be a useful resource with valuable insights. In a similar study that motivated and inspired our investigations, Wilmoth and Ball (1992) analyze the development of public perceptions of population issues, particularly pertaining to population growth, as represented in American popular magazines. They argue that the popular literature serves as a valuable means for analyzing the structure of population arguments, which create a cultural climate influencing policy decisions and intellectual debate. Likewise, social science communication research shows that mass media creates, what Rogers and Storey call, "awareness-knowledge" among the public and stimulates further interpersonal discussion about an issue (1995). 


\subsection{Professional debate over low fertility}

Before we embark on the analyses of the public debate about low fertility, some recent developments in the corresponding professional debate among demographers are worth emphasizing. An intensive review of the literature on low fertility is far beyond the scope of the present paper, and the following presentation is partial and influenced by our own research in that area.

It has been known for quite some time that replacement fertility, which is appealing in terms of population dynamics since it implies a long-term stationary population, constitutes only an "implausible endpoint of the demographic transition" (Demeny 1997a) and is not necessarily an attractor for future fertility trends. In their analyses of sustained below replacement fertility in Europe, demographers therefore frequently refer to the Second Demographic Transition (Lesthaeghe 1983; van de Kaa 1987) that describes a long-term and irreversible transformation of demographic behavior towards low fertility levels, greater individualism and more diverse partnership and fertility patterns. In addition, economic incentives and labor market conditions, especially for young adults, provide an important aspect in demographers' approaches to explaining low fertility (Hotz et al. 1997; Macunovich 1996), although recent evidence suggests that some of the primary relations between female labor market participation and unemployment have been subject to substantial changes. In particular, high fertility in cross-sectional analyses with developed countries tends to be associated with high female labor force participation during the 1990s, quite contrary to the reverse pattern during earlier decades (Ahn and Mira 1998; Hoem 1999; Rindfuss et al. 2000). Exemplary for this reversal are for example Italy and 
Spain, both characterized by relatively low female labor force participation and fertility, while the United States and Nordic countries tend to have achieved both relatively high fertility levels (as compared with European countries) and female participation in the labor market. Differential family policies across these countries may be an important factor in these fertility developments and its relation to labor market behavior (Demeny 1997b; Gauthier 1996; Hoem and Hoem 1990). Still, more research is necessary to fully understand the effect of these different policies.

In addition to the debate about the above determinants of low fertility, the recent introduction of the adjusted total fertility rate has also caused an active academic debate about whether the quantum of contemporary fertility is actually above the level suggested by the total fertility rate and whether concerns about low fertility may be exaggerated because the commonly used demographic measures are distorted due to tempo effects (Bongaarts and Feeney 1998; Kohler and Philipov 2001; Lesthaeghe and Willems 1999). Furthermore, demographers have started to explore the potential limits of low fertility arising from either socio-demographic constraints (Golini 1998b; Namboodiri and Wei 1997) or evolutionary or genetic predispositions for having children (Foster 2000; Kohler et al. 1999). In addressing the question "Why have children in the $21^{\text {st }}$ Century?" Morgan and King (2001) assess a broad range of potential social, economic and biological incentives to have children and conclude biological predispositions supported by a pronatalist context could result in a set of rational decisions that produce moderately high fertility near replacement level. However, the authors are not necessarily optimistic that policy-makers will succeed (or want to succeed) in establishing such a suitable pronatalist context that facilitates higher fertility. In particular, Morgan and King raise doubts that countries with 
current lowest-low fertility levels, such as Italy, will sufficiently change the socioeconomic context of fertility and propose that very low fertility may not merely be a transitory phenomenon in these countries.

The demographic consequences of such sustained below-replacement fertility are well known to demographers (e.g., Coale 1986; Espenshade 1986; Heer 1986; Lee 1994, 2000; McNicoll 1986; Teitelbaum 1997; Weil 1997) and include an aging and possibly shrinking of the population and the labor force. These developments then pose problems to pension and related public support systems, lead potentially to shortages in the labor market and fewer "geniuses," shift political influence towards the elderly, and reduce the long-term innovation and economic growth of populations. Many of these changes are perceived negatively by demographers, and Alfred Sauvy (cited in Coale 1986, p. 214) described a stationary population as a population of old people ruminating over old ideas in old houses. While many of these pessimistic assessments of low fertility are realistic and quite plausible in our opinion, some of the above consequences deserve more careful empirical investigations. Quite unanimous, however, seems to be the consensus among demographers that moderate levels of immigration will do little to curtail population aging, and to a lesser extent, the long-term reduction in population size associated with fertility levels that are substantially below replacement levels.

In addition, low fertility can also imply positive consequences. Individuals experience benefits if being a member of a small cohort improves access to labor market, education, and housing opportunities, as Easterlin (1980) argued. Moreover, continued low fertility also implies a reversal of the arguments that lead to fears about 
population growth (for example, see Erhlich and Lui 1997). In particular, capital deepening in below replacement populations_-in contrast to the capital widening in growing populations - can have positive impacts on labor market productivity and economic growth.

The specific literature on the implications of lowest low fertility, i.e., of total fertility rates that are below 1.3, is still relatively few. In part, the implications of lowest low fertility are extensions of the above demographic work on below replacement fertility and also recent work on population aging (for example, Lee 2000; Martin and Preston 1994). An additional dimension of very low fertility levels, however, arises from a "fear of population decline" (Teilelbaum and Winter 1985, 1998) that is concentrated on non-economic concerns about the size and composition of the population.

\subsection{Public debate over low fertility in context}

The public debate over low fertility reflects some of the above diversity in the academic debate. This investigation in eleven countries across four continents reflects a broad range of fertility experiences, and it reveals considerable variation in public debates over low fertility. We see this variation as caused by two elements: broad clusters of variation based on a country's demographic experience and additional variation based on a country's policy climate.

First, a country's demographic experience-the extent it is below replacement level, the duration it has remained below replacement level, and the speed with which it fell below replacement level—explains broad variations in concern over low fertility. For example, Spain and Japan, which have been at lowest-low levels for years, cluster 
away from other countries that have not experienced very low fertility for very long, like the US.

Second, different policy climates may explain some cross-country variations in concern over low fertility. Most countries included in our study have implemented policies or are initiating discussions to combat shrinking labor forces, squeezed social security funds and deteriorating attitudes towards parenting (Zoubanov 2000). Most notably, France has maintained a pro-natalist family policy for decades, offering both financial support and services for parents. In Germany, family policy is framed as liberal non-intervention: policies serve to allow couples the freedom to chose between work and parenting as they see fit. In contrast, Italy has rushed to implement policy to reduce state imposed financial burdens on parents as raising children has become more expensive. Similarly, amidst high costs of raising children and cultural sanctions on combining work and mothering, Japan has passed laws ensuring greater gender equity and improved public day-care facilities (Zoubanov 2000).

The effectiveness, zeal and consensus with which governments make these policy changes or invite discussion explain some variation in public perceptions of low fertility. As Zoubanov (2000) writes based on the UN Population Policy Data Bank, “Government policies do not always match their satisfaction with demographic parameters." This disjoint between perception and policy creates space for public discussion. Illustrating this point, table 1 provides a view of government perceptions of their countries' demographic situations and their corresponding policy efforts. 
What we find most interesting is that despite this cross-country diversity in demographic experience and policy climate described above, the public debates on low fertility reflect some broad similarities. First, countries emphasize consequences and potential interventions rather than causes in their public debate over low fertility. Second, the public press perceives low fertility as a serious concern with mostly negative implications, despite the fact that many of the causes of low fertility are associated with social and economic progress. Third, the variety of issues and perspectives revealed in the public debate, while cohesive in general ways, invites a role for demographers in informing an accurate public discussion of low fertility, which will help form the most appropriate policy outcomes.

In the following section we first describe our methodology for searching, identifying and coding articles discussing low fertility in the popular press. We then consider the intensity and overall perspective of the low fertility debate in the eleven countries of our study. Subsequently we consider separately the specific causes, consequences and policy interventions that are suggested in the popular debate about low fertility. Finally, we describe in more detail the public debates in the United States, Italy and New Zealand, which are representative of three distinct patterns of debate and concern that emerge from our quantitative analysis.

\section{Methodology}

Articles from eleven countries were analyzed over a two-year period. All countries selected have a TFR under 2.1, and they were chosen to represent a range of demographic experiences, geographic locations and depths of societal concern over low fertility. In addition, only developed countries yielding at least nine relevant 
articles between January 1, 1998 and December 31, 1999 in our press database were considered to ensure a thorough representation of the recent debate over a two-year span. The countries meeting these criteria include Australia, Austria, France, Germany, Italy, Japan, New Zealand, Spain, Switzerland, The United Kingdom, and The United States. Other countries, including Belgium, Bulgaria, Canada, Ireland, Netherlands, Russia, and Sweden, were considered but excluded because no substantial low-fertility debate materialized in the national press. It would be interesting to explore popular press coverage in countries where low fertility debates did not materialize. However, we think that the absence of debate in the countries we excluded only indicates country-specific access limitations of our database; that is, the potential debate in these seven excluded countries could not be thoroughly accessed through our press database described below.

Current events invariably influence the issues covered in the popular press. Still, this analysis covers a two-year time period, which gives ample time to glean a sense of enduring medium- and long-term issues rather than journalistic capriciousness. At the same time, the time period offers the most recent snapshot of contemporary low fertility debates. Inclusion of other media, like television and radio, would have been beyond the means of this project. Furthermore, we are satisfied that the analysis of all articles included in our sources during this time gives us a well-defined group to study systematically. By analyzing articles from several newspapers and magazines for each country, we build a representative set of articles and avoid overstating the case of a few personalities or publication policies. In addition, we chose articles from regional as well as nation sources to thoroughly represent the range of issues low fertility raises. 
In order to identify and retrieve articles discussing low fertility in the media we accessed national and major regional presses of the above eleven countries through the Reuters Business Briefings (RBB) press database. This database catalogues newspapers and some magazines, most in their entirety (exceptions frequently are recipes, letters to the editor, etc.). It offered the most comprehensive, searchable agglomeration of international popular press articles over two years that we could access. Our analyses were restricted to newspapers and magazines that are defined as national or regional presses in the RBB database, thus weeding out newswires' uncertain readership and trade publications' financial-news bias. A list of all newspapers and magazines included in our search is given in the appendix. A more detailed description of the service and a list of all sources catalogued in the RBB database are available at http://www.reuters.com.

The titles, abstracts and complete article texts (where available) of the sources were searched in English, as well as the country's native language if it is not English, including French, German, Italian, and/or Spanish, for articles discussing low fertility. ${ }^{1}$ Swiss sources were searched in English, French and German. Search terms included: in English: low fertility, low birth rate, low birthrate, below replac*, birth dearth; in French: fécondité and natalité; in German: Geburtenrückgang, Bevölkerungsrückgang; in Italian: fecondit*, natalit*; and in Spanish: baja

\footnotetext{
${ }^{1}$ Thanks to Laura Bernardi for Italian translating, Annette Baudisch for German translating, Erin Sines and Raúl Guerra Alonso for Spanish translating, and Nancy Heely for French translating. The foreign language quotes included in the article were translated by these five speakers. In addition, most non-
} 
fecundidad, baja natalidad. ${ }^{2}$ Japanese sources were searched in English only. We recognize the limitations of finding equivalent search terms in five languages and that some relevant articles were excluded using narrow search terms. However, after extensive trial searching, our method identified the vast majority of low-fertility articles while picking up the fewest irrelevant articles. Some countries, like Germany, developed specific vocabularies for low fertility, which allowed narrow search terms. Other countries, like Spain, did not develop specific vocabularies, thus requiring more broad searching and hand weeding of articles. For all countries, irrelevant articles were culled out, including those discussing low or lower fertility in abovereplacement settings, low fertility in an inappropriate context (like low soil fertility), and low fertility as a historical trend followed by a rebound with no mention of contemporary low fertility (for example, some US articles only discussed below replacement fertility in the 1970s followed by a fertility rebound in reference to the current labor market). We did include articles discussing low fertility among cultural or ethnic groups in low fertility settings (like Scots in the UK or Jews in the US). And we also analyzed articles discussing low fertility of regions (like Europe or “developed countries") within a broader text about the world or regions not necessarily experiencing low fertility.

Table 2 provides summary statistics about the articles identified by our search strategy in the respective source countries, the countries where the newspapers or magazines are issued. Our search identified a total of 437 relevant articles, ranging from

English articles were read with a translator and Laura Stark, which allowed for coding validation and consistency.

${ }^{2}$ Search terms ending with an asterisk were recognized in the articles with any word ending. 
countries with 9 articles (Switzerland) to 74 (Australia). The second column reports the number of articles by source and therefore standardizes for the fact that the number of newspapers and magazines included in our database differ for each country. Measured by this indicator, the most active debates about low fertility occur in Italy and France, while the US and New Zealand have the smallest number of low fertility articles per source. Since some newspapers and magazines may not engage at all in the debate about low fertility, we also standardize the total number of articles by the number of sources with at least one article about low fertility (column 3). This measure for intensity of the low fertility debate also reveals that the most active debate occurs in Italy and that the five countries with the most active debates are represented by Italy, France, Austria, Japan, and Australia. The US and New Zealand emerge again as two countries with relatively little public debate on low fertility.

\section{Coding}

The articles identified in our press search were first coded for descriptive characteristics, as for instance: the country that the article comes from; the country, region, or group that the article discusses; and the article date. In addition to the eleven countries used as sources, the discussion has been coded as focusing on the world, developed countries, Scotland, Christians, Jews, Hispanics/Latinos, or Greek

Orthodox. Articles discussing low fertility of a specific industrialized country that did not result in a set large enough to analyze (like Norway, Russia, and Canada) were included under "developed countries" as the debate area. Articles discussing an agglomeration of low fertility countries (for example Spain and Italy), as well as those debating Europe's low fertility were coded as discussing "developed countries" as 
well. The TFR, growth rate, and natural increase of the source country and the country, region, or group discussed were also coded.

Two other general indicators were also recorded—how the article defines low fertility and the article's overall perspective towards low fertility. Though we disregarded the accuracy of the fertility measures used in the articles, it is worth noting that all articles defined low fertility either by a TFR, by another demographic measure (for example, the crude birth rate), or by a general phrase/no specific definition. No article made attempts to distinguish between cohort and period fertility measures or included a reference to potential distortions of these fertility measures by tempo effects (Bongaarts and Feeney 1998). Articles that used general phrases to define low fertility often spoke of below replacement fertility, or simply used the assumption that low fertility was common knowledge, requiring no measured proof.

Next, individual arguments were coded that answered three specific questions: What causes low fertility?; What are the consequences of low fertility?; and What should/can be done about low fertility? Articles could cite more than one argument or give no argument for each question. Articles were analyzed for positive, neutral, or negative discussion of causes and consequences. Arguments offering equally positive and negative perspectives were coded as neutral. In addition, our coding included the discussion of what will be done about low fertility, assertions of what should be done, and descriptions of what is being done. The coding of these interventions distinguished between measures that are aimed at changing low fertility as opposed to those aimed as accommodating low fertility. 


\section{Overall perspective and geographic focus of the low-fertility debate}

Articles' overall perspectives - either positive, negative, or neutral-were more than a culmination of perspectives on specific issues. The overall perspective included the less tangible tone of the article-most importantly, word choice. Articles often avoided taking sides on arguments or offered a balanced perspective on specific causes or consequences of low fertility. However, many used words to describe low fertility with either negative connotations, like crisis, fear, or threat or positive connotations, like progress or victory. These subtleties were reflected in the overall perspective code. Although this classification of an article's overall perspective on low fertility was based on a subjective assessment, the perspective in most cases was relatively apparent and easy to classify.

Despite the relatively broad range of demographic, geographic and socioeconomic contexts that are represented by the different countries in our study, the overall perspectives of the articles on low fertility are mostly negative (62 percent) and otherwise mostly neutral (33 percent). Table 3 shows that across all countries, less than 5 percent of articles identify low fertility as a positive phenomenon, and many of these articles with a positive evaluation consider environmental or ecological consequences. $^{3}$

\footnotetext{
${ }^{3}$ In all tables, averages are calculated based on the total number of articles, rather than weighing each country's or argument's distribution equally.
} 
A quite noticeable divergence across the above countries, however, exists with respect to the consensus on a negative overall perspective. The public opinion in Japan, New Zealand and Spain, as measured by the articles identified in our search, is overwhelmingly negative regarding low fertility with more than 80 percent of all articles having a negative perspective. On the other hand, 50 percent or less of all articles express such a negative perspective in France and the US. The prevalence of these negative or positive perspectives on low fertility is graphed against the total fertility rate in Figure 1. Japan and most European countries are in the top left part of the graph and thus share a relatively low fertility and a relatively negative perspective on low fertility. Australia and New Zealand, on the other hand, do have a relatively high fertility as compared to the European countries, but share their generally negative perspective. The United States in this graph represents the country with the highest total fertility rate and a perspective on low fertility that is quite balanced between negative and neutral/positive. France is clearly an outsider among the European countries, and it is the only country in which most articles reflect a neutral overall perspective on low fertility in our data.

The public debate on low fertility does not have to be concentrated on the country in which the newspaper or magazine is based. In particular, the geographic focus of the debate about low fertility may be an interesting aspect of the debate itself. In Table 4 we therefore tabulate the country or geographic area on which articles focus for the eleven source countries. The most striking observation of this table is that the debate about low fertility seems to be primarily a domestic concern. The vast majority of articles in Australia, Austria, France, Germany, Japan, New Zealand and Spain are concerned with low fertility in the respective countries. Within Europe, only the 
United Kingdom and Switzerland have a low fertility debate that significantly extends beyond national borders. In both countries, the non-national debate is quite evenly spread across other European and developed countries without an outward focus on one particular country. In terms of its geographic orientation, the US debate seems to be quite similar to the debate in the UK with a relatively broad focus on other developed countries. This outward focus dominates press coverage in the US and the UK, despite the two countries being the only ones in which low fertility of a minority group or ethnic group receives some attention.

\section{The causes of low fertility in the popular debate}

Unlike the increasing discussion among demographers about the causes of low fertility, relatively little of the low fertility debate in the media is concerned with the causes of low or declining fertility rates. In the eleven countries included in this study, only about one third of all articles mention at least one cause of low fertility (Table 5). The extent to which causal interpretations are made in the respective debates varies considerably. In our data, only 10 percent of all articles in Japan mention a specific cause of low fertility, while almost 82 percent of all articles in Spain relate low fertility to a specific cause.

We additionally investigated the specific causes of low fertility that were mentioned in the respective national debates in the popular media. In particular, we coded for the following causes of low fertility and additionally one 'other' category for all causes that did not fit into the categories below. 
Changing role of women: Opportunities for women in the workforce or for more life choices are cited as causes under this argument. Feminist vocabulary, describing more opportunity for women, characterize positive views. However, the changing role of women is also described in a negative tone often using traditionalist ideas. Asahi Shimbun explains changing roles in Japan, "The low birth rate is partly attributed to a growing number of women working and marrying later than previous generations. Many women say they would like to get married and have children but are reluctant to do so because a modern marriage has little to offer them."

Economics: This argument is strongly polarized. Some view a strong economy as a disincentive for parenting, arguing that potential parents chose work and wealth over marriage and childbearing. "Turbo-capitalism is not providing the conditions in which young women and men want to get married," said a Melbourne Age (Australia) article. ${ }^{4}$ In addition, stay-at-home parents or caretaker grandparents-important people in prolific societies - are pulled into the workforce because of labor shortages, according to some. On the contrary, a weak economy is also blamed for a sense of insecurity among youth and families, leading to fewer births. The cover article in the August 30, 1999 issue of Germany's Der Spiegel explains:

Children as a burden, whose arrival makes life difficult; or as a luxury, that people cannot or don't want to afford, children as costs. It rings paradoxically_although Germany is one of the richest countries in the world, economic reasons are mainly responsible for the baby gap... When the population shrinks, demand and, with it, investments shrink. Income and

\footnotetext{
${ }^{4}$ October 12, 1999
} 
employment decrease or grow more slowly. In turn, investments shrink further-the beginning of a downward spiral.

Contraceptive knowledge: People know more about preventing pregnancies, and more contraceptive methods are available than in past decades. Progressives, often including young people and feminists, take positive perspectives towards this cause of low fertility, while traditionalists take more negative perspectives. Abortion is also included as a contraceptive issue. As an article in The Australian, date April 21, 1999, states, "The causes of the [fertility] decline are well known..." including “...effective contraception and access to abortion."

Government or employer family policies: Financial and time incentives and disincentives influence childbearing decisions. Regardless of policy motivations, governments and employers influence individual fertility decisions. An article in Austria's Die Presse 5 says that residents are, "having continually fewer children...Criticism of this state of affairs falls on the fact that residents get too little government child support and that women find it very hard to reconcile work and family...Women with more children hardly have a chance to return to their careers."

Social or cultural attitudes: Burgeoning attitudes among potential parents and people influential to them impact fertility decisions. An article in France's Les Echos ${ }^{6}$ takes a neutral perspective on the link between contemporary attitudes and low fertility: "Fertility is largely influenced by the ideas that individuals have about families,"

\footnotetext{
${ }^{5}$ February 23, 1999
} 
particularly their conception of ideal family size. But attitudes like selfishness and materialism are commonly cited in a negative tone, as this quote from the Australian Financial Review ${ }^{7}$ exemplifies, "Children are an irritant to urban lifestyles, so it's not surprising that the most common family in Australia today is one that doesn't have any dependent children..."

Financial costs of having children: The expense of bearing, raising, and schooling children, especially as they leave parental homes later, causes low fertility. An article in Japan's Yomiuri Shimbun ${ }^{8}$ states the argument clearly, "There is no doubt that married couples chose to have fewer children due to the financial burden of childcare." An article in Spain's Cinco Dias ${ }^{9}$ summarizes the low fertility paradox of many Mediteranian countries: "Survivorship of cohesive families facilitates many young people to live longer in the parental home... which radically increases the cost of having children." Understandably, financial costs were most often regarded negatively.

Table 5 also tabulates the frequency with which these specific causes of low fertility are mentioned in the public debate about low fertility. The percentages in the table gives the proportion of article that mention a specific cause among all articles that include at least one specific factor. (More than one cause of low fertility can be mentioned in each article.) Social causes of low fertility, namely the changing role

\footnotetext{
${ }^{6}$ July 8, 1999

${ }^{7}$ August 14, 1999

${ }^{8}$ November 11, 1999

${ }^{9}$ October 22, 1999
} 
women and cultural attitudes, are featured most prominently in the popular press. For instance, in Japan every article that includes causal explanations of low fertility also mentions the changing role of women, and more than one out of four articles does so in the remaining countries. Cultural attitudes is most consistently mentioned in articles across all countries as the cause of low fertility, with the exception of New Zealand. Attitudes like selfishness and material reverie are commonly mentioned among these causes, as well as the incompatibility of children with desired and highly esteemed urban and flexible lifestyles.

While the specific economic aspects related to the costs of children received no particular emphasis, the economic situation in general—a broad range of factors encompassing increasing female labor force participation, increasing job insecurity, material opportunities provided in modern economies, and the like-is mentioned in about one out of five articles. This emphasis seems to be quite common to all the debates about low fertility. Family policies, that is, the financial and policy motivations provided by governments and employers for families, feature prominently in some national debates, as in Austria and to a lesser extent in Japan, Italy and Australia. Interestingly, a family policy debate is absent in the Germany, where many demographers attribute low fertility to deficiencies of the day-care and public support system (e.g., see Kreyenfeld and Hank 2001).

Quite surprisingly is also that contraceptive knowledge and financial costs of children do not feature prominently among these causes, except for Japan and France, where debates surround the impact of the pill, and New Zealand, where a strong abortion debate developed in reference to low fertility. 
Another reading of table 5 across countries also reveals some interesting absences of specific causes in various national debates that are worth mentioning. The causes in the New Zealand discussion, for instance, frequently do not fall into any of the above categories, aside from the contraceptive knowledge cause stemming from an underlying debate on abortion. Although Austria has an active debate about family policies (e.g., Hoem et al. 1999), the specific aspect of child costs—which refers to direct child costs since the notion of opportunity costs is not strongly emphasized in the public debate-does not feature prominently. In the United States, on the other hand, neither the changing role of women, family policies, contraceptive knowledge, nor financial costs receive a strong focus. In particular, the absence of the child-cost argument is striking since in comparison with many European countries the US has probably the least subsidies for day care, schooling and higher education, and other important aspects of child costs (Gauthier 1996). At the same time, with the highest total fertility rate among the eleven countries in our study, the American public is probably least concerned with promoting childbearing.

Table 6 reiterates the prominence of social causes of low fertility in national debates. The changing role of women is mentioned as a cause in 15 percent of all articles and cultural attitudes is mentioned in 14 percent, making them the two most commonly cited causes. Interestingly, these two most common causes making up a "social cause" frame are split regarding perspectives towards them. While one fifth of all articles view the changing role of women as a positive development, second only to better contraceptive knowledge ( 25 percent positive), the cultural attitudes leading to low fertility are portrayed as negative more than half of the time. Still, the divide between 
social and economic/logistical causes of low fertility seen in table 5 extends to table 6 . The three factors causing low fertility most often covered in a negative light are family policies (81 percent), financial costs (80 percent) and economics (59 percent).

\section{The consequences of low fertility in the popular debate}

The debate about low fertility in the popular press seems to be more substantially concerned with the consequences of low fertility, rather than the causes of low fertility, both for individuals and for society at large. On average about two thirds of all articles mentioned at least one consequence, ranging from 36 percent (New Zealand) to 80 percent (United States), as shown in Table 7. (Again, articles could cite more than one consequence of low fertility.) The three countries with the most frequent discussion of low fertility consequences are the United States, the United Kingdom and Germany, while New Zealand, Austria and Italy the have the least representation of potential consequences of low fertility in their public debates.

Similar to our above investigation of low fertility causes in the public debate, we disaggregate the debate about the consequences in nine main topics:

The economy, labor force, or pension system: This triad of consequences is closely linked, and therefore coded together. They also have a wide range of seemingly contradictory perspectives. Some articles herald low fertility in boosting the economy and curbing unemployment. Yet, others state that fewer consumers and labor 
shortages will destroy the current economic system, like this Washington Post ${ }^{10}$ article about Germany:

Having one of the world's lowest birthrates also threatens Germany's future. Soon, one in five Germans will be retired and drawing a large pension, yet the imploding demographic pattern—coupled with an aversion to accepting more immigrants—-means that a much small core of working people will support them.

National well-being: This patriotic argument asserts that low fertility has repercussions on a national level. The source of nations' general senses of spirit and vigor is weighed in these arguments. Negative arguments frame a shrinking population as a loss of vitality. Articles predicting the disappearance of a groupmost popularly, the vanishing of the Japanese population in a given number of centuries if the country's demographics remain constant-is a common scenario in this argument, like this section from The Melbourne Age (Australia): "If present very low birth rates of the Japanese continues for just 200 years, there will be no Japanese people left." Other articles expressed nationalistic concerns about their own countries such as The Independent ${ }^{11}$ (UK): "The fertility rate, 3.5 in 1901, is now down to 1.8 and falling, below replacement level. Which may be okay for the future of the universe but isn't good news for the nation. We lose our brightest and best." This quote recites a common Australian theme ${ }^{12}$ : "This is a truly pathetic result for Australia. It indicates not a national development mentality, but a mindset which has

\footnotetext{
${ }^{10}$ October 3, 1999

${ }^{11}$ August 22, 1998

${ }^{12}$ The Australian; May 9, 1998
} 
accepted that Australia is already in late middle age; a senescent society already in terminal decline, its years of vigor and growth all past." Although our analysis below will show that such negative concerns about the implications of low fertility on the national well-being dominate in the public debate, a few articles also welcome "fewer quality people" as the base of a quality nation.

Power distribution: Threats to power—both physical and political—can be felt on a regional and international level because of low fertility (Teitelbaum and Winter 1985, 1998). The prospect of a declining population size is viewed as a threat for some nations equating human numbers with power. An Australian ${ }^{13}$ article titled "No Real Future without Body of Inhabitants", said low fertility will result in “...pressure from crowded neighboring countries and a declining say in world affairs." Likewise, low fertility is often perceived as changing regional power distributions, which disrupt the balance within nations. For example, heated articles from the United Kingdom debate the validity of re-distributing seats in parliament because of the declining number of Scots. The Scotsman ${ }^{14}$ quotes one expert as saying, "Scottish low fertility is distinct in its lowness...We are all dying out, but the Scots are dying out faster than others. This raised the political question of how much representation a dying breed deserves." A changing power distribution is usually seen as either positive or negative, depending on the author's allegiance.

The ecological environment: This classic issue in population debates (e.g., Clarke 1996) is most often discussed in a positive tone. Regardless of the numbers, the fewer

\footnotetext{
${ }^{13}$ July 16,1998
} 
the people, the better the environment, as this Melbourne Age (Australia) ${ }^{15}$ article illustrates, “...for some environmentalists, for whom there can scarcely ever be too few humans, this is good news."

Women, parents, or families: Low fertility impacts individuals or family members on a personal level. Individuals' lifestyles are different than they would be with any children or with more children. Laura Balbo, Italy's Equal Opportunity Minister, frames this consequence of low fertility in a positive light in a La Stampa $^{16}$ article saying, "More women have time for politics since they are not so busy raising so many children.”

Family structure: This consequence impacts an institution, rather than individuals. The article's impression of family structure — as it is or as it should be-is changed by low fertility. The Economist ${ }^{17}$ reported that due to low fertility, "A more subtle but equally profound change will be in the structure of the family. The chances are that today's 6 billionth child will enjoy two or three siblings, a bevy of adoring aunts and uncles, a clutch of cousins. Baby number 7,500,000,000 is more likely to be an only child, with few relatives of her own generation." Similarly, an article in the Swiss Neue Züricher Zeitung titled, "Germany: The Alarm Call of Demographers," says that low fertility causes "worry about structural changes in the area of the family. An

\footnotetext{
${ }^{14}$ February 5, 1998

${ }^{15}$ October 12, 1999

${ }^{16}$ January 19, 1999

${ }^{17}$ Sept 25, 1999
} 
increasingly individualistic lifestyle disintegrates traditional family connections even more."

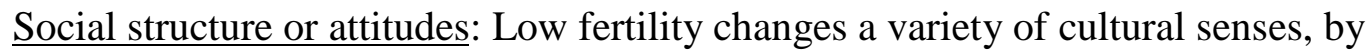
incorporating new multicultural influences, for example, or redefining the age mentality of a culture. Upon stating that low fertility will create "quite a different type of society from today", The Independent ${ }^{18}$ author expanded, "What politicians need to think about is the impact an aging electorate will have on social attitudes. An older population will inevitably have different ideas about how a society should be organized from a younger one. Call these 'Bournemouth values,' for want of a better expression: a desire for a more orderly society."

Infrastructure: Low fertility has direct, tangible effects on schools, roads, hospitals, and the military service. The Berliner Zeitung ${ }^{19}$ explains school closings because of Germany's low fertility: "For [the municipal education administrator] school planning is a difficult job. For years, the number of students in his district has continually decreased. The base of this trend is low fertility..." An earlier article in the same paper quotes a representative of the Union for Education and Science regarding the low fertility rates as saying, "In the upcoming school year, we're expecting chaos."

Other: A commonly cited consequence of low fertility is an aging population. Many articles discuss longevity and aging as an issue complementary to low fertility. However, in the analysis in this paper, aging is only tabulated as a consequence when

\footnotetext{
${ }^{18}$ Oct 6, 1999
} 
it is explicitly framed as a consequence of low fertility. For instance, an article in Japan's Asahi Shimbun ${ }^{20}$ makes the link explicit, "A low birth rate is accelerating the aging of society..." In many countries there may also be a debate on population aging that has no reference to low fertility, and these debates are not included in our search strategy.

Across all countries, the implications of low fertility for the economy in general, the labor force and the pension system are most prominently mentioned. Moreover, these various economic consequences of low fertility are presented quite consistently across all countries ranging from 32 percent in Japan to 83 percent in Switzerland. The second most important consequence of low fertility in the public debate pertains to national well-being, that is, to the non-economic implications of low fertility on the size and composition of the future population. An outlier in that context is clearly the debate in New Zealand, where as many as three out of four articles associate implications for the national well-being with low fertility. Although at a lower level, concern about the national well-being is also consistently present in the debates in Australia, Austria and France, and it occurs more sporadically in the remaining countries. The distribution of a country's relative power in economic and political terms, both domestically and internationally, features also regularly in the debates in Australia, France, Switzerland, and the United Kingdom. Among these countries, France has had a traditional concern about low fertility as compared to its neighboring countries that is documented from the $19^{\text {th }}$ century onward. In Australia, on the other hand, this concern seems in part be due by the relatively low fertility of Australians as

\footnotetext{
19 June 6, 1999
} 
compared to their South-Asian neighbors whose growing populations may exert immigration pressure into Australia or reduce the relative political influence of Australia in that area. With a more domestic focus, the political power distribution of the UK being debated because of the shrinking number of Scots who retain the same representation in parliament. Somewhat surprising in our study is the relative absence of a debate about the implications of low fertility on the family structure. While the demographic influence of low fertility on the structure and composition of families is out of question from a scientific perspective (Wachter 1997), only a subset of national debates in Austria, Italy, Spain, Switzerland and the UK reflect this implication of low fertility.

The above discussion of the perceived consequences of low fertility in the public debate focused on the presence of certain arguments in the debate. In addition, we also investigate whether a specific implication or consequence of low fertility is also associated with an evaluation of the respective social and economic changes. Table 8 therefore tabulates the consequences of low fertility by the respective evaluation in the debates. For most consequences, the evaluation seems to be relatively polarized. The implications for the economy, labor force and pension system are overwhelmingly perceived negatively, as are the consequences for national well-being and power distribution. Quite strikingly, the only aspect where the consequences of low fertility are seen overwhelmingly in a positive light is in the area of the ecological environment. A more balanced evaluation between neutral and negative, but almost never positive perspective, exists for the consequences for family structure, social

\footnotetext{
${ }^{20}$ July 18, 1998
} 
structure and attitudes, and infrastructure. A mixed evaluation that includes both positive and negative perspectives seems to exist in the assessment of low fertility consequences for women, parents and families.

\section{Interventions for low fertility in the popular debate}

In light of the overall negative assessment of low fertility it is not surprising that potential interventions are an important aspect in the public debate about low fertility.

On average nearly half of the articles on low fertility suggest specific interventions to reduce the negative consequences associated with persistent below-replacement fertility, ranging from 20 percent in the US to 86 percent in Spain (tables 9A and 9B). These suggested interventions to accommodate or change low fertility in the public debate fall into two primary categories:

Change low fertility: Five different types of interventions suggested ways to change low fertility. Articles suggest raising fertility through more parent-friendly policies from employers or the government, often in terms of time and money allocation; limiting reproductive services, like access to contraceptives or abortion; returning to traditional social values, often framed through the male-breadwinner paradigm; exploring more progressive social values, like creating a shared-parenting norm and new social resource models; and economic revitalization to boost national spirit or cut the financial burden of children. 
One more extreme suggestion for limiting low fertility comes from The Southland Times $^{21}$ (New Zealand): “Things can change; the challenge for Invercargill city is to make policies to alter the demographic framework. Invercargill Mayor Tim Shadbolt said the council had to be inventive in it's approach such as offering rates relief for people who produced more than six children. (stet) 'We have to plan a major power cut or ban television, it's the only hope we've got."'

Accommodate low fertility: The articles identified in our study also offered four different resolutions to low-fertility problems without raising fertility. The resolutions offered solutions to economic, pension, and workforce problems linked with having fewer people. The resolutions included, changing immigration policies; encouraging new workers like women, youth, or senior citizens in the workforce; changing career structure, like the number of hours worked or the retirement age, to retain the same workers with higher productivity; and making specific changes to the pension system. Specific recommendations to accommodate low fertility suggested in Austria's Die Presse $e^{22}$ included, "later retirement, continued job training, more private insurance, and redistribution of government funds from younger cohorts to older."

Tables 9A and 9B show that immigration and parent-friendly policies are most consistently mentioned in that debate. Considerable variation, however, exists in the prevalence of these arguments. While low fertility in Australia seems to be strongly associated with a debate about immigration, the debate in New Zealand is much more concerned with policy interventions that focus on the already resident population. A

\footnotetext{
${ }^{21}$ August 26, 1999
} 
discussion of immigration as a potential reaction to persistent low fertility is also relatively absent in Japan, and although about two thirds of all articles include policy suggestions, these seem to focus on family policy and economic interventions. In most other countries, family policies and immigration are represented parallel to each other in the public debate about low fertility, and only a combination of internal and external focus is perceived as being able to change and/or accommodate persistent below replacement fertility. Other possibilities of the government to intervene in low fertility situations are mentioned more sporadically. For instance, a revitalization of the economy is mentioned to some extent in the debates in Australia, Austria, France, Germany, Japan and Spain, while limiting reproductive health services, namely restricting abortion, are discussed in New Zealand.

A second, less direct and less controllable intervention addresses the area of values and social attitudes. However, the direction of these interventions diverge. One side of the public debate about low fertility seems to suggest a return to more traditional values and attitudes to rebuild the higher-fertility cultural contexts of the past. Still, another side suggests the adoption of new and more progressive norms and values that allow the combination of new child-rearing partnerships, different lifestyles conducive to childbearing, and more contemporary parent roles.

\footnotetext{
${ }^{22}$ March 15, 1999
} 


\section{Patterns of concern over low fertility}

Three case study countries— the US, Italy and New Zealand—exemplify common patterns of concern about low fertility. Cultural and policy contexts are important for understanding nuance, cross-country variation in concern over low fertility. However, juxtaposing the level of concern in the popular press with demographic measures helps explain the broad consistencies we found. These three patterns of concern described below are also illustrated in Figure 1, which shows source countries' overall perspectives toward low fertility plotted against their total fertility rates.

Projected population growth in the next decades, little concern about low fertility: The $\underline{\text { case of the United States }}$

The US public lacks strong concern about low fertility since fertility levels are close to replacement level. Concerns about the consequences of low fertility are thus relatively rare, and the discussion tends to focus on other demographic trends instead. This dearth of alarm about low fertility contrasts with academic concern over and public awareness of a changing population distribution, namely aging, and its impacts on the US social security system. By current projections, the cost of social security benefits will exceed the revenues earmarked for the system after 2014. Lee (2000) points out that problems with the American social security system "have been prominent in news report", and we suggest, these concerns supercede domestic low fertility concerns in the public conscience and popular press. An active demographic debate on aging may therefore be developing in the American popular press and public conscience, however, our media search on low fertility did not pick it up since the public discussion about aging was disregarded in this study unless it was explicitly linked to low fertility. 
Furthermore, lack of concern over low fertility in the US may also be a function of two fertility experiences. First, with a TFR of 2.06, policy allowing 900,000 documented immigrants per year, and population growth that is projected to continue in the US at least through 2050 (Table 9), the US is not experiencing the social and economic consequences of low fertility that countries with a TFR near 1 experience more harshly. Second, the US is experiencing below replacement fertility among nonHispanic white, Asian, and American Indian sub-populations, while fertility is slightly above replacement level among blacks (2.2) and at a TFR of 3.0 for Hispanics. ${ }^{23}$ As a result, low fertility is not a cross-cutting experience, and for most sub-populations below replacement level fertility is a recent trend. This varying fertility of sub-groups points to American diversity. As a traditional immigrant nation, there is little uniform American culture defined in racial and ethnic terms that may need protection, as is argued in other countries with a more ethnicity-based national identity. In summary, aging, rather than low fertility, is associated with economic concerns resulting from demographic changes in the US, and below replacement fertility currently does not pose a "threat" to American culture and society because of its established tradition as an immigrant country with substantial social and cultural heterogeneity.

Projected population decline in the next decades, strong concern about low fertility:

The case of Italy

Italy shares a similar pattern of concern about low fertility with other European countries, particularly Spain. Though the nuances of the arguments vary, the essence

\footnotetext{
${ }^{23}$ Population Reference Bureau, AmeriStat: http://www.ameristat.org/racethnic/fertility.htm
} 
of low fertility threatening the country—-through policy struggles, cultural loss, and economic decline-dominates public concern.

Low fertility elicits deep public concern throughout Europe because it hits the core of two systems with strong popular attachments: social support policy and cultural heritage. First, Italy has generous social systems, deemed both a cause of low fertility and the most prominent striking point of low fertility. To manage low fertility, Italy must change its demographic trends or substantially reverse or alter established social programs (Golini 1998a, b). In addition, Italy is steeped in cultural tradition, wellrecognized for the importance of family connections, as reflected by the popular attachments to la mamma. Cultural heritage is being transformed by the changing structure of the family and the population distribution, as well as changing values towards women, children, foreigners and the elderly.

The language used in the public debate about low fertility to suggest remedies for the perceived negative consequences—both political and social—hangs with an awareness of a fascist past in Italy and also Germany. Interventions to change low fertility, rather than change policies to match demographics, dictate private behavior to better the state and protect culture. Part of the public concern with low fertility in Europe is that, because of her history, solutions do not come easy. The cover story in Germany's Der Spiegel explores the historical meaning of low fertility in Italy: "Similarly taboo as a targeted immigration policy, is an active population policy-it arouses association with attempts of the Fascists. In 1927 Mussolini introduced a tax in Italy for single men and paid a premium for marriages and births. The state, that today reigns by consensus, has to be kept out of the bedroom." 
Projected population growth in the next decades, strong concern about low fertility: The case of New Zealand

New Zealand is characteristic of perhaps the most surprising cases. In the previous two cases, when a country's demographic variables are considered, its sentiments towards low fertility follow logically. The inverse relationship between concern and demographics—-high growth, low concern and low growth, high concern-is somewhat intuitive. However, another pattern of concern does exist, which does not match this predictable inverse relationship between growth and concern.

Like the US, New Zealand's population growth is strong, though its TFR of 1.8 dips slightly below the US's and replacement level. Nevertheless, New Zealand's population will not stabilize for at least another fifty years, by United Nations medium variant projections. Based on its demographic indicators, we expected public sentiment in New Zealand to be close to that in the US: with barely-belowreplacement fertility and continued net population growth, low fertility does not seem to constitute a problem.

However, the New Zealand public has responded to the contrary, with more than 80 percent of the articles on low fertility giving a negative perspective, more than that of both the US and Italy. New Zealand illustrates that concern towards low fertility is relative to a country's historical fertility levels and to the fertility levels of neighboring countries. 
While slightly-below-replacement fertility has been relatively stable in the US, this is a recent and somewhat sudden development in New Zealand, diverging from historically above-replacement fertility. New Zealand's alarmed reaction to slightlylow fertility is reminiscent of France during the late 1960s and early '70s. While France's fertility was still above replacement level in 1967, the government was nonetheless concerned about its downward trend and commissioned a study on ways to increase fertility, namely the birth of a third child (United Nations 1989; Teitelbaum and Winter1985). In addition, New Zealand's fertility is strikingly low relative to its developing neighbors. As reflected in the country's articles, New Zealand's national-well being is threatened by low fertility, translating into a lack of national vigor, while in terms of fertility, its neighbors in Southeast Asia thrive.

\section{Discussion and concluding remarks}

Our investigation into the public debate about low fertility in eleven developed countries clearly reveals that the issue of low fertility, often representing social and economic gains, conjures alarm among the popular press and the public. Though below-replacement fertility rates have existed in many developed countries for decades and public debates over low fertility periodically erupted in individual countries and in different eras (see Teitelbaum and Winter 1985), broad speculation over the consequences of contemporary low fertility has remained mainly an academic concern. The reasons for the emergence of this recent low fertility debate may be twofold. On one hand, below-replacement fertility rates did not result in net population decline until recently due to population momentum, increasing life expectancy, and immigration. On the other hand, only the last decade brought about lowest low fertility levels on a national scale that are below 1.3 for prolonged periods 
of time. The direct implications of the contemporary low fertility rate—on public policy, economics, and social identity—therefore had not touched the public because again population momentum, mortality declines and immigration served as a buffer as long as fertility was only modestly below replacement, pushing population growth despite below replacement fertility rates. Since the most severe consequences of low fertility were a subject of the future, the low fertility debate frequently remained ostensibly academic. In addition, in the 1960s and 1970s, when below-replacement fertility superceded the Baby Boom in many developed countries, low fertility was seen as an antidote to fresh concerns about high fertility in many developed nations at that time. Indeed, many countries in this study_including the US, Japan, Australia and the UK-initiated research on the impact of domestic overpopulation during this time (Gauthier 1996).

We find, in agreement with the United Nation's Population Inquiry Survey conducted among developed countries in 1989, that fertility levels alone are not the sole determinant of how satisfied countries are with their demographic situations in recent years. Instructed by the New Zealand case study and the other countries experiencing slightly-below-replacement fertility at the same time as serious concern about low fertility, we find that other demographics—namely net population growth or decline as well as aging — along with social considerations_- like attachment to an ethnicallybased national identity and value of traditional family structures and roles-play a vital role in determining concern.

Undoubtedly, low fertility is a serious concern in the public view, as shown by the volume and range of discussion as well as the negativity of most perspectives. 
Furthermore, the variety of issues and perspectives revealed in the public debate, while cohesive in general ways, invites a role for demographers in informing an accurate public discussion of low fertility, which will help form the most appropriate policy outcomes. Starting with a discussion of how low contemporary fertility is, including insight from both the adjustment of the total fertility rate and comparisons of cohort and period fertility, to an informed evaluation of the connection between socioeconomic conditions, family policies and fertility levels, there seems be a considerable need for demographers to contribute to the public discussion on the causes of low fertility. In addition, the strong emphasis on the consequences of low fertility in the public debates provide a unique opportunity for demographers to inform and shape a highly policy-relevant discussion about the social, economic and political consequences of future population change. In particular, the role of demographers in this discussion should extend beyond the provision of accurate measurements of fertility and projections about future trends, to include an active professional discussion on the consequences and potential remedies of the most recent trends. 
Appendix A. Reuters Business Briefing Source Categorizations

\begin{tabular}{|c|c|c|c|}
\hline Country & Publication & Language & Text Type \\
\hline \multicolumn{4}{|l|}{ Germany } \\
\hline & Berlin Zeitung & German & National, Full-text \\
\hline & Boersen Zeitung & English & National, Abstract \\
\hline & Der Spiegel & German & National, Full-text \\
\hline & Die Woche & German & National, Full-text \\
\hline & $\begin{array}{l}\text { Frankfurter Allgemein } \\
\text { Zeitung }\end{array}$ & German & National, Full-text \\
\hline & General Anzeiger & German & Regional, Abstract \\
\hline & Handelsblatt & English & National, Abstract \\
\hline & Passauer Neue Press & German & Regional, Full-text \\
\hline & Stuttgarter Zeitung & German & Regional, Full-text \\
\hline & Suddeutsch Zeitung & German & National, Full-text \\
\hline & TAZ & German & National, Full-text \\
\hline \multicolumn{4}{|l|}{ Austria } \\
\hline & Der Standard & German & National, Full-text \\
\hline & Die Presse & German & National, Full-text \\
\hline \multicolumn{4}{|l|}{ Australia } \\
\hline & Age (Melbourne) & English & $\begin{array}{l}\text { Regional, Full- } \\
\text { text, Daily and } \\
\text { Sunday }\end{array}$ \\
\hline & Australian & English & National, Full-text \\
\hline & Australian Financial Review & English & National, Full-text \\
\hline & Canberra Times & English & Regional, Full-text \\
\hline & Courier Mail & English & Regional, Full-text \\
\hline & Daily Telegraph & English & National, Full-text \\
\hline & Herald Sun & English & $\begin{array}{l}\text { Regional, Full- } \\
\text { text, Daily and } \\
\text { Sunday }\end{array}$ \\
\hline & Illawara Mercury & English & Regional, Full-text \\
\hline & The Mercury & English & Regional, Full-text \\
\hline & Sunday Mail Adelaide & English & Regional, Full-text \\
\hline & Sydney Morning Herald & English & Regional, Abstract \\
\hline & West Australian & English & Regional, Full-text \\
\hline \multicolumn{4}{|c|}{ New Zealand } \\
\hline & Christchurch Press & English & Regional, Full-text \\
\hline & Daily News & English & Regional, Full-text \\
\hline & Dominion & English & Regional, Full-text \\
\hline & Evening Post & English & Regional, Full-text \\
\hline & Evening Standard & English & Regional, Full-text \\
\hline & Independent Business & English & National, Full-text \\
\hline & Weekly & & \\
\hline & Nelson Mail & English & Regional, Full-text \\
\hline & New Zealand Herald & English & National, Full-text \\
\hline & Southland Times & English & Regional, Full-text \\
\hline & Timaru Herald & English & Regional, Full-text \\
\hline
\end{tabular}




\begin{tabular}{|c|c|c|c|}
\hline & Waikato Times & English & Regional, Full-text \\
\hline & Chicago Tribune & English & National, Full-text \\
\hline & Los Angeles Times & English & National, Full-text \\
\hline & Washington Post & English & National, Full-text \\
\hline & Aberdeen American News & English & Regional, Abstract \\
\hline & Akron Beacon Journal & English & Regional, Abstract \\
\hline & Anchorage Daily News & English & Regional, Abstract \\
\hline & Appleton Post-Crescent & English & Regional, Abstract \\
\hline & Arizona Republic & English & Regional, Abstract \\
\hline & Asbury Park Press & English & Regional, Abstract \\
\hline & $\begin{array}{l}\text { Atlanta Journal and } \\
\text { Constitution }\end{array}$ & English & Regional, Abstract \\
\hline & Augusta Chronicle & English & Regional, Abstract \\
\hline & Austin American-Statesman & English & Regional, Abstract \\
\hline & Bakersfield Californian & English & Regional, Abstract \\
\hline & Belleville News-Democrat & English & Regional, Abstract \\
\hline & Biloxi Sun Herald & English & Regional, Abstract \\
\hline & Boston Globe & English & Regional, Abstract \\
\hline & Boulder Daily Camera & English & Regional, Abstract \\
\hline & Bradenton Herald & English & Regional, Abstract \\
\hline & Cedar Rapids Gazette & English & Regional, Abstract \\
\hline & Centre Daily Times & English & Regional, Abstract \\
\hline & Charleston Gazette & English & Regional, Abstract \\
\hline & Charleston Post and Courier & English & Regional, Abstract \\
\hline & Charlotte Observer & English & Regional, Abstract \\
\hline & $\begin{array}{l}\text { Colorado Springs Gazette } \\
\text { Telegraph }\end{array}$ & English & Regional, Abstract \\
\hline & Columbus Ledger-Enquirer & English & Regional, Abstract \\
\hline & Commentary & English & National, Abstract \\
\hline & Contra Costa Times & English & Regional, Abstract \\
\hline & Daily Oklahoman & English & Regional, Abstract \\
\hline & Dallas Morning News & English & Regional, Abstract \\
\hline & Denver Post & English & Regional, Abstract \\
\hline & Detroit Free Press & English & Regional, Abstract \\
\hline & Duluth News-Tribune & English & Regional, Abstract \\
\hline & Eugene Register-Guard & English & Regional, Abstract \\
\hline & Florida Times Union & English & Regional, Abstract \\
\hline & Forbes & English & National, Abstract \\
\hline & Fort Wayne News-Sentinel & English & Regional, Abstract \\
\hline & Fort-Worth Star-Telegram & English & Regional, Abstract \\
\hline & Fresno Bee & English & Regional, Abstract \\
\hline & Gilroy Dispatch & English & Regional, Abstract \\
\hline & Grand Forks Herald & English & Regional, Abstract \\
\hline & Hackensack Record & English & Regional, Abstract \\
\hline & Harrisburg Patriot & English & Regional, Abstract \\
\hline & Herald Journal & English & Regional, Abstract \\
\hline & Houston Chronicle & English & Regional, Abstract \\
\hline
\end{tabular}




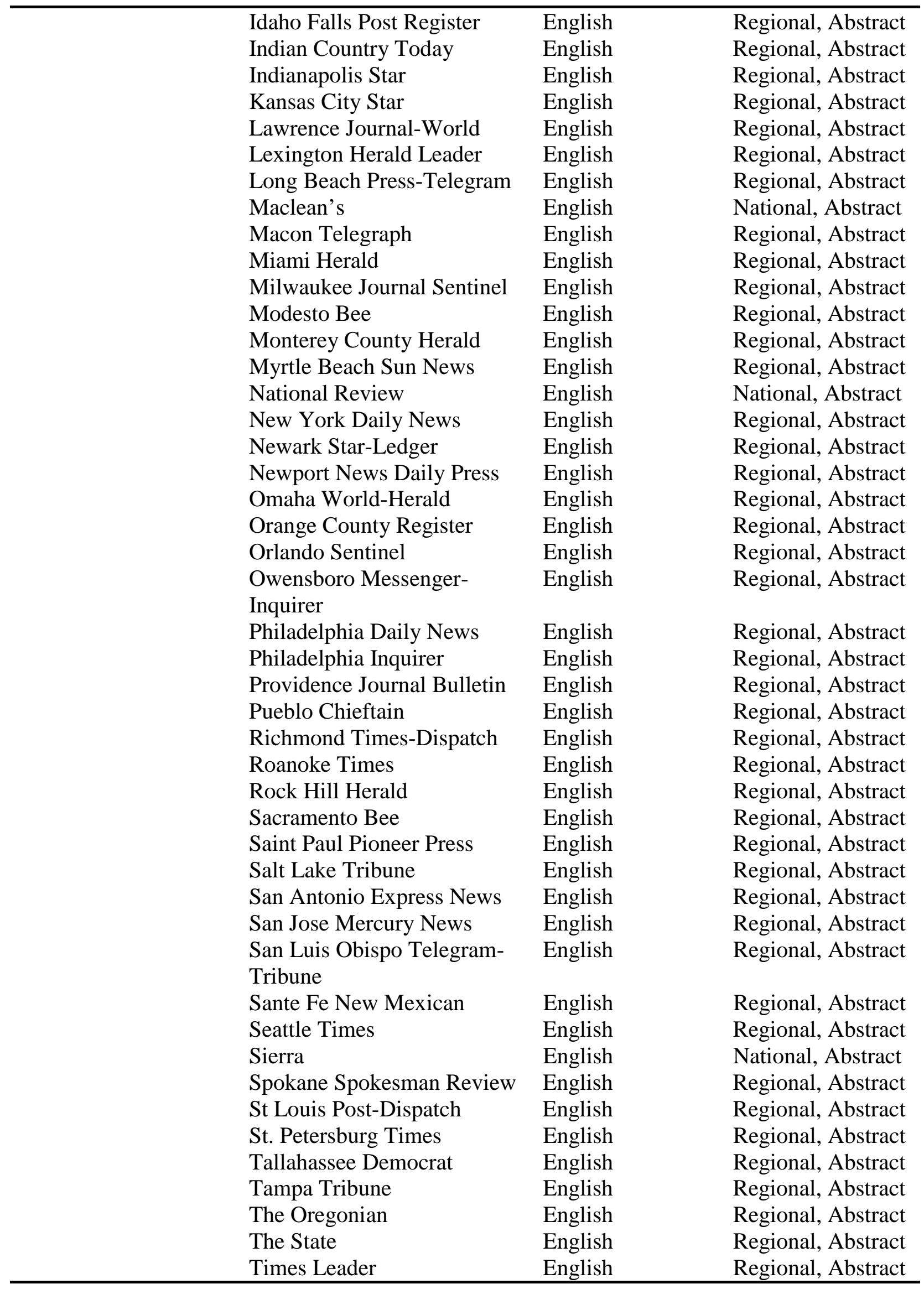




\begin{tabular}{|c|c|c|c|}
\hline & Tri-City Herald & English & Regional, Abstract \\
\hline & Tulsa World & English & Regional, Abstract \\
\hline & Virginia-Pilot & English & Regional, Abstract \\
\hline & Wichita Eagle & English & Regional, Abstract \\
\hline & Wisconsin State Journal & English & Regional, Abstract \\
\hline \multicolumn{4}{|l|}{ The United Kingdom } \\
\hline & Aberdeen Press and Journal & English & Regional, Full-text \\
\hline & Birmingham Post & English & Regional, Full-text \\
\hline & Cornish Guardian & English & Regional, Full-text \\
\hline & Daily Mail & English & National, Full-text \\
\hline & Daily Post & English & National, Full-text \\
\hline & Daily Telegraph & English & National, Full-text \\
\hline & Eastern Daily Press & English & Regional, Full-text \\
\hline & Economist & English & National, Full-text \\
\hline & Evening Standard & English & Regional, Full-text \\
\hline & Guardian & English & National, Full-text \\
\hline & Independent & English & National, Full-text \\
\hline & Manchester Evening News & English & Regional, Full-text \\
\hline & Mirror & English & National, Full-text \\
\hline & Northern Echo & English & Regional, Full-text \\
\hline & People & English & National, Full-text \\
\hline & Scotland on Sunday & English & National, Full-text \\
\hline & Scottish Daily Record & English & Regional, Full-text \\
\hline & Sunday Mail & English & Regional, Full-text \\
\hline & Sunday Telegraph & English & National, Full-text \\
\hline & Sunday Times & English & National, Full-text \\
\hline & The Scotsman & English & National, Full-text \\
\hline & Times & English & National, Full-text \\
\hline & Western Morning News & English & Regional, Full-text \\
\hline & Yorkshire Post & English & Regional, Full-text \\
\hline \multicolumn{4}{|l|}{ Switzerland } \\
\hline & Basler Zeitung & German & National, Full-text \\
\hline & $\mathrm{CASH}$ & German & National, Full-text \\
\hline & FACTS & German & National, Full-text \\
\hline & L'Agefi & French & National, Full-text \\
\hline & Neue Zuericher Zeitung & German, English & $\begin{array}{l}\text { National, Full-text } \\
\text { (German) and }\end{array}$ \\
\hline & Tages Anzeiger & German & $\begin{array}{l}\text { Abstract (English) } \\
\text { National, Full-text }\end{array}$ \\
\hline \multicolumn{4}{|l|}{ Italy } \\
\hline & Corriere della Sera & Italian & National, Full-text \\
\hline & Il Sole & English & National, Abstract \\
\hline & La Stampa & Italian & National, Full-text \\
\hline \multicolumn{4}{|l|}{ France } \\
\hline & L'AGEFI & English & National, Abstract \\
\hline & Le Figaro & English & National, Abstract \\
\hline & Le Monde & French, English & $\begin{array}{l}\text { National, Full-text } \\
\text { (French) and }\end{array}$ \\
\hline
\end{tabular}




\begin{tabular}{|c|c|c|c|}
\hline & Les Echos & French, English & $\begin{array}{l}\text { Abstract (English) } \\
\text { National, Full-text } \\
\text { (French) and } \\
\text { Abstract (English) }\end{array}$ \\
\hline & Liberation & French & Regional, Full-text \\
\hline \multicolumn{4}{|l|}{ Spain } \\
\hline & $\mathrm{ABC}$ & Spanish & National, Full-text \\
\hline & Cinco Dias & Spanish, English & $\begin{array}{l}\text { National, Full-text } \\
\text { (Spanish) and } \\
\text { Abstract (English) }\end{array}$ \\
\hline & El Mundo & Spanish & National, Full-text \\
\hline & El Pais & Spanish, English & $\begin{array}{l}\text { National, Full-text } \\
\text { (Spanish) and } \\
\text { Abstract (English) }\end{array}$ \\
\hline & Expansion & Spanish & National, Full-text \\
\hline & Gaceta de los Negocios & Spanish & National, Full-text \\
\hline & La Vanguardia & Spanish, English & $\begin{array}{l}\text { National, Full-text } \\
\text { (Spanish) and } \\
\text { Abstract (English) }\end{array}$ \\
\hline \multicolumn{4}{|l|}{ Japan } \\
\hline & Asahi Shimbun & English & National, Full-text \\
\hline & Daily Yomiuri & English & National, Full-text \\
\hline & Kyodo News & English & National, Full-text \\
\hline & Mainichi Daily News & English & National, Full-text \\
\hline & Nikkei Weekly & English & National, Full-text \\
\hline
\end{tabular}




\section{Acknowledgements}

The authors would like to thank several scientists at the Max Planck Institute for

Demographic Research for their contributions and insights, including Gunnar Andersson, Laura Bernardi, Francesco Billari, Christoph Buhler, Karsten Hank, Iliana Kohler, Michaela Kreyenfeld, and Jose Antonio Ortega. We also appreciate the language and technical support of Annette Baudisch, Erin Sines, Raúl Guerra Alonso and Nancy Vaupel. Furthermore, we gratefully acknowledge the support for this research by the Max Planck Institute for Demographic Research, where Laura Stark was visiting while major parts of this work were conducted.

\section{References}

Ahn, Namkee and Pedro Mira. 1998. "Changing relationship between fertility and female employment in developed countries," paper presented at the Annual Meeting of the European Society for Population Economics, Amsterdam.

Bongaarts, John and Griffith Feeney. 2000. "On the quantum and tempo of fertility: A reply," Population and Development Review, forthcoming.

Clarke, J. I. 1996. "The impact of population change on environment: An overview," in Bernardo Colombo, Paul Demeny, and Max F. Perutz (eds.), Resources and Population: Natural, Institutional and Demographic Dimensions of Development. Oxford: Clarendon Press.

Coale, Ansley J. 1986. "Demographic effects of below-replacement fertility and their social implications," Population and Development Review 12, supplement: 203216.

Demeny, Paul. 1997a. "Replacement-level fertility: The implausible endpoint of the demographic transition,” in G.W. Jones, R.M. Douglas, J.C. Caldwell, and R. 
M. D’Sousa (eds.) The Continuing Demographic Transition. Oxford: Claredon Press.

_ 1997b. "Policy Interventions," paper presented at the United Nations Population Division Expert Group Meeting on Below-Replacement Fertility, New York.

Espenshade, Thomas J. 1986. "Population dynamics with immigration and low fertility," Population and Development Review 12, supplement: 248-261.

Foster, Caroline. 2000. “The limits to low fertility: A biosocial approach," Population and Development Review 26, no. 2: 209-234.

Gauthier, Anne Helene. 1996. The State and the Family: A Comparative Analysis of Family Policies in Industrialized Countries. New York: Oxford University Press.

Golini, Antonio. 1998a. "Demographics, public spending and social programs," Labour 12, no. 1: 119-141.

_ 1998b. "How low can fertility be? An empirical exploration," Population and Development Review 24, no.1: 59-74.

Heer, David M. 1986. "Immigration as a counter to below-replacement fertility in the United States," Population and Development Review 12, supplement: 262-269.

Hoem, Britta. 2000. "Entry into motherhood in Sweden: The influence of economic factors on the rise and fall in fertility, 1986-1997," Demographic Research 2, no. 4: online at http://www.demographic-research.org

Hoem, Jan M. 1990. "Social policy and recent fertility change in Sweden,” Population and Development Review 16, no. 4: 735-748.

Hoem, Jan M., Alexia Prskawetz, and Gerda Neyer. 1999. “Third births in Austria: The effect of public policies, educational attainment and labor-force 
attachment," working paper 1999-002 for Max Planck Institute for Demographic Research, Rostock, Germany.

Hotz, Joseph V. and Klerman, Jacob A. and Willis, Robert J. 1997. "The Economics of Fertility in Developed Countries," in Mark R. Rosenzweig and Oded Stark (eds.) Handbook of Population and Family Economics, Amsterdam: Elsevier.

Kohler, Hans-Peter and Dimiter Philipov. 2001. "Variance effects and nonlinearities in the Bongaarts-Feeney formula," Demography 38(1): 1-16.

Kohler, Hans-Peter, Joseph L. Rodgers and Christensen, Kaare. 1999. "Is fertility behavior in our genes: Findings from a Danish twin study," Population and Development Review 25, no. 2: 253-288.

Kreyenfeld, M. and K. Hank. 2000. "Does the availability of childcare influence the employment of mothers? Findings from western Germany," Population Research and Policy Review 19, no. 3.

Lee, Ronald D. 2000. “Long-term population projections and the US social security system," Population and Development Review 26, no. 1:137-143.

Lee, Ronald D. 1994. "The formal demography of population aging, transfers, and the economic life cycle," in L. Martin and S. Preston (eds.) The Demography of Aging, Washington, D.C.: National Academy Press.

Lesthaeghe, Ron. 1983. “A century of demographic and cultural change in Western Europe: An exploration of underlying dimensions," Population and Development Review 9, no. 3: 411-435.

Lesthaeghe, Ron and Paul Willems. 1999. "Is low fertility a temporary phenomenon in the European Union?” Population and Development Review 25, no. 2: 211229. 
Macunovich, D. J. 1996. "Relative income and price of time: exploring their effects on US fertility and female labor force participation," Population and Development Review 22, supplement: 223-257.

Martin, Linda G. and Samuel H. Preston. 1994. The Demography of Aging. Washington, D. C.: National Academy Press.

Morgan, S. Philip and Rosalind B. King. 2001. "Why have children in the 21st century? Biological predispositions, social coercion, rational choice," European Journal of Population, 71 (1): 3-20.

Namboodiri, K. and L. Wei .1997. "Fertility theories and their implications how low can low fertility be," paper presented at The Twenty-third IUSSP General Population Conference, Beijing.

Rindfuss, Ronald R., Karen Benjamin and S. Philip Morgan. 2000. “The changing institutional context of low fertility," paper presented at the annual meeting of the Population Association of America, Los Angelos.

Rogers, Everett and J. Douglas Storey. 1995. "Communication campaigns," in Charles R. Berger and Steven H. Chaffee (eds.) Handbook of Science Communication, London: Sage Publications.

Teitelbaum, Michael S. and Jay Winter. 1985. The Fear of Population Decline. London: Academic Press.

Teitelbaum, Michael. 1997. "Consequences of sustained below-replacement fertility," paper presented at the United Nations Population Division Expert Group Meeting on Below-Replacement Fertility, New York.

Teitelbaum, Michael S. and Jay Winter. 1998. A Question of Numbers: High Migration, Low Fertility and the Politics of National Identity. New York: Hill \& Wang. 
United Nations. 1989. "Trends in population policies," no. 114 in Population Studies. New York: United Nations.

van de Kaa, Dirk J. 1987. “Europe's second demographic transition,” Population Bulletin 42, no. 1: 1-57.

Wachter, Kenneth W. 1997. "Kinship resources for the elderly," Philosophical Transactions of The Royal Society of London Series B, Biological Sciences 352, no. $1363: 1811-1817$.

Weil, David N. 1997. “The economics of population aging,” in Mark R. Rosenzweig and Oded Stark (eds.) Handbook of Population and Family Economics, Amsterdam: Elsevier.

Wilmoth, John R. and Patrick Ball. 1992. "The population debate in American popular magazines, 1946-90," Population and Development Review 18, no. 4: 631-668.

Zoubanov, Anatoly. 2000. "Population ageing and population decline: government views and policies," United Nations Expert Group Meeting on Policy Responses to Population Ageing and Population Decline, October 16-18, New York. 
Table 1. Government Views and Policies Towards Growth, Fertility and Immigration, 1999

\begin{tabular}{lcccccc}
\hline & \multicolumn{2}{c}{ Population Growth } & \multicolumn{2}{c}{ Fertility } & \multicolumn{2}{c}{ Immigration } \\
& View & Policy & View & Policy & View & Policy \\
\hline Australia & Satisfactory & No intervention & Satisfactory & No intervention & Satisfactory & Maintain \\
Austria & Too low & No intervention & Too low & Raise & Too high & Lower \\
France & Satisfactory & No intervention & Too low & No intervention & Too high & Lower \\
Germany & Satisfactory & No intervention & Too low & No intervention & Too high & Lower \\
Italy & Satisfactory & No intervention & Too low & No intervention & Satisfactory & Maintain \\
Japan & Satisfactory & No intervention & Too low & No intervention & Satisfactory & Maintain \\
New Zealand & Satisfactory & No intervention & Satisfactory & No intervention & Satisfactory & Maintain \\
Spain & Satisfactory & No intervention & Too low & No intervention & Satisfactory & Maintain \\
Switzerland & Satisfactory & No intervention & Too low & No intervention & Too high & Lower \\
United Kingdom & Satisfactory & No intervention & Satisfactory & No intervention & Satisfactory & Lower \\
United States & Satisfactory & No intervention & Satisfactory & No intervention & Satisfactory & Maintain \\
\hline
\end{tabular}

Based on the UN Population Policy Data Bank from Anatoly Zoubanov, "Population ageing and population decline: government views and policies" October 2000. 
Table 2. Articles Discussing Low Fertility

\begin{tabular}{lccc}
\hline & Number of Articles & Articles per Source & Articles per Sources Used \\
\hline Australia & 74 & $6.17(5)$ & $6.73(5)$ \\
Austria & 26 & $13.00(3)$ & $13.00(3)$ \\
France & 88 & $17.60(2)$ & $22.00(2)$ \\
Germany & 34 & $3.78(7)$ & $4.25(7)$ \\
Italy & 63 & $21.00(1)$ & $31.50(1)$ \\
Japan & 39 & $7.80(4)$ & $7.80(4)$ \\
New Zealand & 11 & $1.00(10)$ & $2.20(10)$ \\
Spain & 36 & $5.14(6)$ & $5.14(6)$ \\
Switzerland & 9 & $2.25(8)$ & $3.00(9)$ \\
United Kingdom & 37 & $1.54(9)$ & $3.36(8)$ \\
United States & 20 & $0.21(11)$ & $1.82(11)$ \\
$\quad$ TOTAL & 437 & 2.47 & 6.33 \\
\hline
\end{tabular}

Note: Column rank in parenthesis

Source: US Bureau of the Census, Mid-year 1999 projection 
Table 3. Distribution of Articles' Overall Perspectives by Source Country

\begin{tabular}{lccc}
\hline & Positive (\%) & Neutral (\%) & Negative (\%) \\
\hline Australia & 1 & 23 & $76(4)$ \\
Austria & 0 & 42 & $58(9)$ \\
France & 14 & 53 & $33(11)$ \\
Germany & 0 & 41 & $59(8)$ \\
Italy & 2 & 38 & $60(7)$ \\
Japan & 3 & 10 & $87(1)$ \\
New Zealand & 0 & 18 & $82(2)$ \\
Spain & 6 & 14 & $81(3)$ \\
Switzerland & 0 & 33 & $67(6)$ \\
United Kingdom & 5 & 22 & $73(5)$ \\
United States & 10 & 40 & $50(10)$ \\
$\quad$ AVERAGE & 5 & 33 & 62 \\
\hline
\end{tabular}

Notes: All articles were coded for overall perspective towards low fertility. Column rank is in parenthesis. 
Table 4. Article Source Country by Debate Area

Source Country

\begin{tabular}{|c|c|c|c|c|c|c|c|c|c|c|c|}
\hline & $\begin{array}{c}\text { Australia } \\
(\%)\end{array}$ & $\begin{array}{c}\text { Austria } \\
(\%)\end{array}$ & $\begin{array}{c}\text { France } \\
(\%)\end{array}$ & $\begin{array}{c}\text { Germany } \\
(\%)\end{array}$ & $\begin{array}{l}\text { Italy } \\
(\%)\end{array}$ & $\begin{array}{c}\text { Japan } \\
(\%)\end{array}$ & $\begin{array}{l}N Z \\
(\%)\end{array}$ & $\begin{array}{c}\text { Spain } \\
(\%)\end{array}$ & $\begin{array}{c}\text { Switzerld. } \\
(\%)\end{array}$ & $\begin{array}{l}\text { UK } \\
(\%)\end{array}$ & $\begin{array}{l}\text { USA } \\
(\%)\end{array}$ \\
\hline \multicolumn{12}{|l|}{ COUNTRY } \\
\hline Australia & 88 & & & & & & & & & & \\
\hline Austria & & 92 & & & & & & & & & \\
\hline France & & & 69 & & & & & & & & \\
\hline Germany & & & 2 & 91 & 3 & & & & 11 & 8 & 5 \\
\hline Italy & & 4 & 3 & & 89 & & & & & 3 & 5 \\
\hline Japan & 4 & 4 & 1 & 3 & & 100 & & 3 & 11 & 5 & 20 \\
\hline New Zealand & & & & & & & 91 & & & & \\
\hline Spain & & & 3 & & & & & 92 & & 3 & \\
\hline Switzerland & & & 3 & 3 & & & & & 22 & & \\
\hline United Kingdom & & & 1 & & & & & & & 35 & \\
\hline United States & & & & & & & & & & 3 & 30 \\
\hline \multicolumn{12}{|l|}{ OTHER } \\
\hline Developed Countries & 1 & & 7 & 3 & 6 & & & 3 & 22 & 10 & 10 \\
\hline Minority Group & & & & & & & & & & 10 & 10 \\
\hline Other Countries & & & & & & & & & 11 & 5 & 5 \\
\hline World & 7 & & 9 & & 2 & & 9 & 3 & 22 & 15 & 15 \\
\hline
\end{tabular}

"Developed Countries" are articles that discuss these countries as one region. "Other Countries" are developed countries not included in the table that are discussed individually in articles (i.e. Norway). 
Table 5. Distribution of Low Fertility Causes by Source Country

\begin{tabular}{|c|c|c|c|c|c|c|c|c|c|}
\hline & $\begin{array}{c}\text { Cause } \\
\text { Mentioned } \\
(\%)\end{array}$ & $\begin{array}{c}\text { Cause } \\
\text { Mentioned } \\
\text { (N) }\end{array}$ & $\begin{array}{c}\text { Role of } \\
\text { Women } \\
(\%)\end{array}$ & $\begin{array}{l}\text { Economics } \\
(\%)\end{array}$ & $\begin{array}{l}\text { Contracptv. } \\
\text { Knowldg. } \\
(\%)\end{array}$ & $\begin{array}{c}\text { Family } \\
\text { Policies } \\
(\%)\end{array}$ & $\begin{array}{c}\text { Cultural } \\
\text { Attitudes } \\
(\%)\end{array}$ & $\begin{array}{c}\text { Costs } \\
(\%)\end{array}$ & $\begin{array}{c}\text { Other } \\
(\%)\end{array}$ \\
\hline Australia & 41 & 30 & 57 & 33 & 17 & 40 & 40 & 10 & 20 \\
\hline Austria & 23 & 6 & 33 & 17 & 0 & 83 & 50 & 0 & 17 \\
\hline France & 38 & 33 & 55 & 21 & 36 & 27 & 39 & 9 & 6 \\
\hline Germany & 24 & 8 & 25 & 13 & 13 & 0 & 38 & 25 & 25 \\
\hline Italy & 37 & 23 & 39 & 22 & 13 & 35 & 57 & 26 & 9 \\
\hline Japan & 10 & 4 & 100 & 0 & 25 & 50 & 50 & 50 & 0 \\
\hline New Zealand & 36 & 4 & 25 & 0 & 50 & 0 & 0 & 0 & 50 \\
\hline Spain & 75 & 27 & 19 & 22 & 7 & 19 & 57 & 26 & 9 \\
\hline Switzerland & 44 & 4 & 25 & 25 & 0 & 25 & 50 & 0 & 0 \\
\hline United Kingdom & 30 & 11 & 45 & 18 & 18 & 9 & 45 & 18 & 9 \\
\hline United States & 15 & 3 & 0 & 33 & 0 & 0 & 26 & 7 & 7 \\
\hline AVERAGE & 35 & 153 & 42 & 22 & 18 & 29 & 40 & 13 & 12 \\
\hline
\end{tabular}

Note: Articles could cite more than one cause of low fertility. 
Table 6. Perspectives Toward Low Fertility Causes

\begin{tabular}{lcccc}
\hline & $\begin{array}{c}\text { Cause } \\
\text { Mentioned }(\%)\end{array}$ & $\begin{array}{c}\text { Positive } \\
(\%)\end{array}$ & $\begin{array}{c}\text { Neutral } \\
(\%)\end{array}$ & $\begin{array}{c}\text { Negative } \\
(\%)\end{array}$ \\
\hline Changing Role of Women & 15 & 20 & 63 & 17 \\
Economics & 8 & 15 & 26 & 59 \\
Contraceptive Knowledge & 6 & 25 & 54 & 21 \\
Family Policies & 10 & 2 & 16 & 81 \\
Cultural Attitudes & 14 & 5 & 39 & 56 \\
Financial Costs & 5 & 0 & 18 & 82 \\
Other & 4 & 5 & 37 & 58 \\
\hline
\end{tabular}


Table 7. Distribution of Low Fertility Consequences by Source Country

\begin{tabular}{|c|c|c|c|c|c|c|c|c|c|c|c|}
\hline & $\begin{array}{c}\text { Consequence } \\
\text { Mentioned } \\
(\%)\end{array}$ & $\begin{array}{l}\text { Consequence } \\
\text { Mentioned } \\
\text { (N) }\end{array}$ & $\begin{array}{l}\text { Economy, } \\
\text { Labor } \\
\text { Pension } \\
(\%)\end{array}$ & $\begin{array}{l}\text { National } \\
\text { Well- } \\
\text { being } \\
(\%)\end{array}$ & $\begin{array}{c}\text { Power } \\
\text { Distribtn. } \\
(\%)\end{array}$ & $\begin{array}{c}\text { Environt. } \\
(\%)\end{array}$ & $\begin{array}{c}\text { Women, } \\
\text { Parents, } \\
\text { Families } \\
(\%)\end{array}$ & $\begin{array}{c}\text { Family } \\
\text { Structure } \\
(\%)\end{array}$ & $\begin{array}{l}\text { Social } \\
\text { Structure, } \\
\text { Attitds. } \\
(\%)\end{array}$ & $\begin{array}{c}\text { Infrastr. } \\
(\%)\end{array}$ & $\begin{array}{c}\text { Other } \\
(\%)\end{array}$ \\
\hline Australia & 69 & 51 & 47 & 37 & 20 & 16 & 0 & 0 & 8 & 4 & 22 \\
\hline Austria & 46 & 12 & 33 & 33 & 0 & 0 & 0 & 25 & 8 & 17 & 33 \\
\hline France & 69 & 61 & 70 & 33 & 16 & 15 & 10 & 5 & 16 & 0 & 2 \\
\hline Germany & 82 & 28 & 43 & 4 & 0 & 4 & 0 & 0 & 7 & 43 & 14 \\
\hline Italy & 63 & 40 & 32 & 13 & 3 & 0 & 6 & 10 & 13 & 16 & 19 \\
\hline Japan & 56 & 22 & 59 & 9 & 0 & 0 & 5 & 0 & 9 & 18 & 23 \\
\hline New Zealand & 36 & 4 & 50 & 75 & 0 & 0 & 0 & 0 & 0 & 0 & 0 \\
\hline Spain & 72 & 26 & 38 & 8 & 8 & 0 & 4 & 23 & 4 & 12 & 8 \\
\hline Switzerland & 67 & 6 & 83 & 17 & 17 & 0 & 0 & 17 & 33 & 17 & 17 \\
\hline United Kingdom & 76 & 28 & 57 & 7 & 18 & 18 & 0 & 11 & 4 & 7 & 18 \\
\hline United States & 80 & 16 & 63 & 13 & 6 & 19 & 0 & 6 & 6 & 6 & 6 \\
\hline AVERAGE & 67 & 294 & 52 & 21 & 11 & 9 & 4 & 7 & 13 & 11 & 14 \\
\hline
\end{tabular}

Note: Articles could cite more than one consequence of low fertility 
Table 8. Perspectives Toward Low Fertility Consequences

\begin{tabular}{lcccc}
\hline & $\begin{array}{c}\text { Consequence } \\
\text { Mentioned (\%) }\end{array}$ & $\begin{array}{c}\text { Positive } \\
(\%)\end{array}$ & $\begin{array}{c}\text { Neutral } \\
(\%)\end{array}$ & $\begin{array}{c}\text { Negative } \\
(\%)\end{array}$ \\
\hline Economy, Labor Force, Pension & 34 & 3 & 15 & 82 \\
National Well-being & 14 & 3 & 7 & 90 \\
Power Distribution & 7 & 0 & 20 & 80 \\
Ecological Environment & 6 & 89 & 4 & 8 \\
Women, Parents, Families & 2 & 30 & 30 & 40 \\
Family Structure & 5 & 5 & 45 & 50 \\
Social Structure, Attitudes & 8 & 8 & 27 & 65 \\
Infrastructure & 7 & 3 & 25 & 72 \\
Other & 9 & 5 & 33 & 63 \\
\hline
\end{tabular}


Table 9A. Suggested Interventions for Changing Low Fertility by Source Country

\begin{tabular}{|c|c|c|c|c|c|c|c|c|}
\hline & $\begin{array}{c}\text { Intervention } \\
\text { Suggested (\%) }\end{array}$ & $\begin{array}{c}\text { Intervention } \\
\text { Suggested (N) }\end{array}$ & $\begin{array}{c}\text { Parent Friendly } \\
\text { Policies (\%) }\end{array}$ & $\begin{array}{l}\text { Limiting Health } \\
\text { Services (\%) }\end{array}$ & $\begin{array}{l}\text { Traditional } \\
\text { Values (\%) }\end{array}$ & $\begin{array}{l}\text { Progressive } \\
\text { Values (\%) }\end{array}$ & $\begin{array}{c}\text { Revitalize } \\
\text { Economy (\%) }\end{array}$ & $\begin{array}{l}\text { Other } \\
(\%)\end{array}$ \\
\hline Australia & 66 & 49 & 43 & 6 & 14 & 4 & 4 & 8 \\
\hline Austria & 73 & 19 & 79 & 5 & 0 & 11 & 5 & 11 \\
\hline France & 57 & 50 & 26 & 0 & 10 & 16 & 10 & 2 \\
\hline Germany & 32 & 11 & 27 & 0 & 0 & 0 & 9 & 27 \\
\hline Italy & 44 & 28 & 36 & 0 & 4 & 0 & 0 & 7 \\
\hline Japan & 38 & 15 & 33 & 0 & 7 & 13 & 7 & 20 \\
\hline New Zealand & 73 & 8 & 50 & 50 & 0 & 0 & 0 & 0 \\
\hline Spain & 86 & 31 & 32 & 0 & 3 & 6 & 10 & 10 \\
\hline Switzerland & 78 & 7 & 14 & 0 & 0 & 14 & 0 & 14 \\
\hline United Kingdom & 32 & 12 & 33 & 17 & 8 & 17 & 0 & 8 \\
\hline United States & 20 & 4 & 25 & 0 & 0 & 25 & 0 & 0 \\
\hline AVERAGE & 54 & 234 & 37 & 4 & 7 & 9 & 6 & 9 \\
\hline
\end{tabular}

Note: Articles could cite more than one intervention to change low fertility 
Table 9B. Suggested Interventions for Accommodating Low Fertility by Source Country

\begin{tabular}{|c|c|c|c|c|c|c|c|}
\hline & $\begin{array}{c}\text { Intervention } \\
\text { Suggested (\%) }\end{array}$ & $\begin{array}{c}\text { Intervention } \\
\text { Suggested (N) }\end{array}$ & $\begin{array}{c}\text { Immigration } \\
(\%)\end{array}$ & $\begin{array}{l}\text { Encourage } \\
\text { Workers (\%) }\end{array}$ & $\begin{array}{l}\text { Change Career } \\
\text { Structure (\%) }\end{array}$ & $\begin{array}{l}\text { Change Pension } \\
\text { System (\%) }\end{array}$ & $\begin{array}{l}\text { Other } \\
(\%)\end{array}$ \\
\hline Australia & 66 & 49 & 80 & 0 & 2 & 0 & 0 \\
\hline Austria & 73 & 19 & 21 & 0 & 11 & 5 & 5 \\
\hline France & 57 & 50 & 32 & 10 & 32 & 38 & 2 \\
\hline Germany & 32 & 11 & 55 & 0 & 18 & 36 & 0 \\
\hline Italy & 44 & 28 & 43 & 0 & 0 & 11 & 7 \\
\hline Japan & 38 & 15 & 7 & 7 & 7 & 33 & 13 \\
\hline New Zealand & 73 & 8 & 13 & 0 & 0 & 0 & 0 \\
\hline Spain & 86 & 31 & 32 & 10 & 19 & 16 & 6 \\
\hline Switzerland & 78 & 7 & 43 & 14 & 14 & 29 & 14 \\
\hline United Kingdom & 32 & 12 & 25 & 17 & 33 & 25 & 0 \\
\hline United States & 20 & 4 & 25 & 0 & 50 & 25 & 0 \\
\hline AVERAGE & 54 & 234 & 41 & 5 & 15 & 18 & 4 \\
\hline
\end{tabular}

Note: Articles could suggest more than one intervention to accommodate low fertility. 
Figure 1. Total Fertility Rate by Percentage of Negative Articles

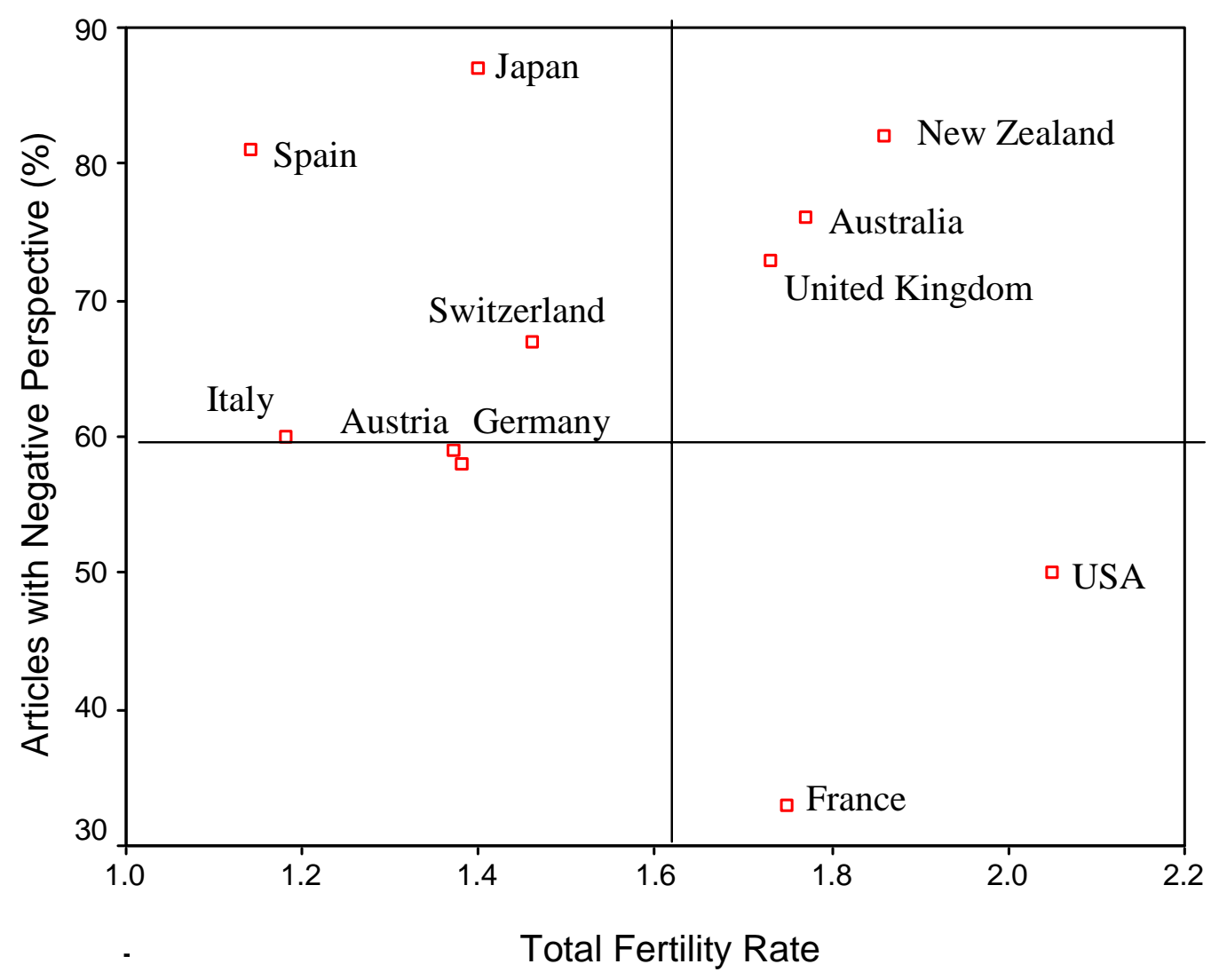

